\title{
KESANTUNAN BERBAHASA DI MEDIA SOSIAL ONLINE: TINJAUAN DESKRIPTIF PADA KOMENTAR BERITA POLITIK DI FACEBOOK
}

\author{
Muncar Tyas Palupi dan Nafisah Endahati \\ Universitas PGRI Yogyakarta \\ muncartyas@gmail.com/ nafisah_indahatinya@gmail.com
}

\begin{abstract}
Abstrak: Penelitian ini bertujuan untuk mendeskripsikan bentuk kesantunan berbahasa dalam unggahan berita dan komentar berita di Facebook. Penelitian ini menggunakan pendekatan kualitatif deskriptif. Sumber data penelitian ini terbatas pada unggahan berita politik saja. Mengingat isi unggahan bermacam-macam dan jumlah unggahan setiap hari sangat banyak. Objek penelitian ini adalah percakapan di grup FB dengan subjek penelitian adalah percakapan berita politik. Metode pengumpulan data yang dipakai dalam penelitian ini adalah metode simak dan tulis, yakni dengan menyimak penggunaan bahasa. Pelaksanaan pengumpulan data pada penelitian ini adalah metode simak yang diwujudkan melalui teknik dasar dan teknik lanjutan. Teknik dasarnya disebut teknik sadap, sedangkan teknik lanjutannya adalah teknik simak bebas libat cakap dan teknik catat. Hasil dari penelitian ini adalah ditemukannya berbagai bentuk kesantunan berbahasa dalam unggahan berita dan komentar berita politik nampak dalam empat hal, yaitu (1) penggunaan pronomina, (2) penggunaan bentuk ketidaklangsungan, penggunaan kata kunci, dan (4) penggunaan kalimat bersifat empati.
\end{abstract}

Kata Kunci: Kesantunan berbahasa, media sosial online, berita politik, facebook

Abstract: The research aims to describe form of language politeness in uploaded news and comment in Facebook. This research was conducted in descriptive qualitative methodology. Source of research data was limited to political uploaded news in considering with the various uploaded content and the unlimited amount of uploaded news. The object of the research was the Facebook group conversation and the subject of the research was the political news conversation. The data collection method used the referral and writing methods. The implementation of data collection in this research was the referral method that was realized through basic and advanced techniques. The basic technique named tapping technique, while the advanced technique named free speech technique and note technique. The research results the discovery of various forms of language politeness in uploaded news and political news comment seen from four things, namely (1) the use of pronominal, (2) the use of form of continuity, (3) the use of key words, and (4) the use of empathetic sentences.

Key words: language politeness, online social media, political news, Facebook

\section{PENDAHULUAN}

Kaidah kesantunan umumnya dipakai dalam setiap tindak berbahasa. Sopan santun atau tata krama adalah salah satu wujud penghormatan seseorang kepada orang lain. Penghormatan atau penghargaan terhadap sesama bersifat manusiawi.Saling menghargai merupakan salah satu kekhasan manusia sebagai makhluk berakal budi, yaitu makhluk yang berilakunya senantiasa 
berdasarkan pada pertimbangan akal budi daripada insting (Baryadi, 2005:71).

Sopan santun berbahasa disebut pula tata krama berbahasa atau etiket berbahasa. Dasar terciptanya sopan santun berbahasa adalah sikap penutur kepada mitra tutur yang terwujud dalam penggunaan bahasanya. Sopan santun berbahasa merupakan sikap hormat penutur kepada mitratutur yang diwujudkan dalam tuturan yang sopan dan tuturan yang sopan dilahirkan dari sikap yang hormat pula (Baryadi dalam Pranowo, 2005:71).

Media sosial online merupakan media yang didesain untuk memudahkan interaksi sosial bersifat interaktif dengan berbasis teknologi internet. Menurut Kurniawan (2017:220) media online adalah alat yang mengubah pola penyebaran informasi dari sebelumnya bersifat broadcast media monologue (satu ke banyak audiens) menjadi ke social media dialogue (banyak audiens ke banyak audiens).

Di era internet ini, jenis media sosial online sangat beragam. Salah satunya yang paling populer adalah Facebook. Facebook atau situs jejaring sosial ini lahir di Cambridge, Massachusetts 14 Februari 2004 oleh Mahasiswa Harvard bernama Mark Zuckerberg. Menurut data di Alexa, Facebook adalah mesin jejaring sosial nomor satu. Dalam urutan keseluruhan situs di dunia, Facebook menempati rangking ke5 setelah Yahoo, Google, YouTube, dan Windows Live. Kepopuleran Facebook di Indonesia, mulai tahun 2008 dengan jumlah spektakuler pengguna Facebook yakni sebesar $618 \%$.

Facebook dibuat dengan niat yang baik, digunakan untuk mengusung nilai-nilai pertemanan yang "kental". Hal itu dapat dilihat pada fitur dan kemampuan seperti membuat pertemanan dan terus dapat berhubungan dengan teman-teman atau relasi, personal whiteboards atau umumnya disebut "walls", membuat group, tergabung ke dalamnya, advertising parties/"events", mengirimkan pesan personal layaknya $e$ mail, saling meng-upload dan sharing image, campus advertising, serta membuat pernyataan status.

Ketertarikan peneliti untuk mengkaji kesantunan postingan dan komentar pada berita politik ini didasari beberapa alasan. Pertama, unggahan berita yang diposting sangat update. Kedua, setiap informasi yang diunggah (postingan) umumnya mengundang komentar yang sangat banyak dan beragam tanggapan dari para pembacanya. Ketiga, anggotanya yang beragam yang berasal dari berbagai latar belakang pendidikan dan usia menyebabkan munculnya bentuk kalimat dan tanggapan dengan bahasa sangat bervariatif.

Rumusan masalah dalam penelitian ini adalah bagaimanakah bentuk kesantunan berbahasa dalam unggahan berita dan komentar berita politik di Facebook? Tujuan penelitian ini adalah mendeskripsikan bentuk kesantunan berbahasa dalam unggahan berita (posting) dan komentar pembaca di Facebook.

\section{METODE PENELITIAN}

Penelitian ini menggunakan pendekatan kualitatif deskriptif. Pada langkah awal peneliti mengumpulkan fakta atau data pada suatu latar alamiah. Latar alamiah yang dimaksud di sini adalah tuturan-tuturan dalam komunikasi komentar berita politik yang dijadikan sebagai sumber data langsung. Penelitian ini mementingkan proses daripada hasil. Penelitian ini menghasilkan data yang berupa kata-kata atau kalimat unggahan berita dan tanggapanyang santun dalam berita politik di facebook.

Peneliti secara murni hadir sebagai seorang yang mengamati dan mengumpulkan data yang berupa tuturantuturan tertulis pada dinding percakapan kolom komentar berita politik. Kehadiran 
peneliti tidak diketahui oleh orang-orang yang terlibat dalam dialog berita dan komentar. Peneliti hanya mengamati dan mencatat data yang dibutuhkan dalam penelitian ini. Menurut Moleong (2006) instrumen penelitian kualitatif adalah peneliti itu sendiri sebagai alat pengumpul data.

Sumber data penelitian ini terbatas pada unggahan berita kecelakaan saja. Mengingat isi unggahan bermacam-macam dan jumlah unggahan setiap hari sangat banyak. Berita politik yang menjadi objek dalam penelitian ini adalah berita yang diunggah selama peristiwa politik pencalonan presiden hangat pada tahun 2018.

Metode pengumpulan data yang dipakai dalam penelitian ini adalah metode simak dan tulis, yakni dengan menyimak penggunaan bahasa. Metode simak tersebut yang diwujudkan melalui teknik dasar dan teknik lanjutan. Teknik dasarnya disebut teknik sadap, sedangkan teknik lanjutannya adalah teknik simak bebas libat cakap dan teknik catat (berkaitan dengan metode dan teknik, baca Sudaryanto 2015).

Langkah-langkah penelitian ini adalah sebagai berikut; 1) peneliti mengklasifikasi data yang telah diidentifikasi kesantunannya menurut bentuk dan fungsi tuturan, serta penanda aspek kebahasaan yang menunjukkan kesantunan 2) hasil identifikasi tersebut diklasifikasikan menurut realisasi kesantunan tuturannya, 3) hasil analisis dicek keabsahannya atau kredibilitasnya oleh rekan sejawat, dan 4) peneliti membuat kesimpulan berupa keteraturan dalam merealisasikan kesantunan berkomunikasi dalam komunikasi unggah berita dan komentar berita politik.

\section{HASIL DAN PEMBAHASAN}

Unggahan informasi berita dalam sehari terdapat lebih dari 30 informasi berita. Rata-rata informasi politik berkisar antara 5-10 berita dalam sehari. Penyampaian informasi berita tidak hanya berwujud verbal tetapi banyak yang disertai dengan informasi gambar. Tentunya penyajian gambar ini disertai maksud agar informasi secara visual juga tersajikan sehingga informasi menjadi terpercaya. Baryadi (dalam Pranowo,2005:71) menjelaskan, menurut jenis perilakunya sopan santun dapat dibedakan menjadi dua jenis, yaitu sopan santun nonverbal dan sopan santun verbal. Sopan santun nonverbal adalah sopan santun perilaku biasa seperti makan, minum, bertamu, bergaul, berpakaian, dan berjalan. Sopan santun verbal merupakan sopan santun perilaku dengan menggunakan bahasa atau sopan santun berbahasa. Realisasinya seperti sopan santun berbicara, menyapa, menyuruh, menelepon, berterima kasih, meminta maaf, mengritik.

Baryadi (dalam Pranowo, 2005:71) mengemukakan bahwa sopan santun berbahasa adalah seperangkat prinsip yang disepakati oleh masyarakat bahasa untuk menciptakan hubungan yang saling menghargai antara anggota masyarakat pemakai bahasa yang satu dengan anggota yang lain.

\section{Bentuk Kesantunan dalam Berita dan Komentar di Berita Politik}

\section{Penggunaan Pronomina}

Sebuah interaksi sosial akan terjalin dengan baik jika syarat-syarat tertentu terpenuhi, salah satunya adalah kesadaran akan bentuk sopan santun. Bentuk sopan santun dapat diungkapkan dengan berbagai hal.Salah satu penanda sopan santun adalah penggunaan bentuk pronomina dalam percakapan (Kushartanti, 2005:105).

Pada unggahan berita, untuk menyebut pembaca, penggunggah menyapa dengan kata "Pak" dan "Mas". "Pak" yang 
merupakan singkatan dari kata "Bapak", dan "Mas" yang merupakan singkatan dari "Kamas"

(1) V: Selamat... sy dan seluruh keluarga pilih pak Ridwan.Jgn kecewakan kami. Satu masukan buat Bpk....tolong sarana2 yg sdh bpk buat lebih diperhatikan pemeliharaannya krn byk yg rusak....(K)

(2) IA: @N sudah mas tinggal nunggu aja nih keputusan KPU provinsi. Kalau ada kecurangan mmg lebih bagus segera dikumpul bukti dan dilaporkan.. karena itu saya tidak setuju kalau kita2 hanya menggerutu di FB ini tanpa bertindak $(\mathrm{K})$

\section{Penggunaan}

Bentuk

\section{Ketidaklangsungan}

Bentuk lain dari sopan santun adalah pengungkapan suatu hal dengan cara tidak langsung. Salah satu bentuk ketidaklangsungan dapat ditemukan di dalam maksud yang tersirat di dalam suatu ujaran. Di dalam hal ini, ketidaklangsungan mensyaratkan kemampuan seseorang untuk menangkap maksud yang tersirat, misalnya menanggapi sebuah kalimat yang diujarkan orang lain sebagai sebuah perintah. Maksud yang terkandung di dalam ujaran itu disebut implikatur (Kushartanti, 2005:106). Pranowo (2009) mengatakan dalam berkomunikasi masyarakat Jawa tidak hanya mengandalkan pikiran. Meskipun yang ingin dikomunikasikan adalah buah pikiran, tetapi ketika akan menyampaikan maksud kepada mitratutur, biasanya terlebih dahulu berusaha menjaga perasaan mitratutur (njaga rasa).

(3) M: Mahathir itu negarawan yg cinta negaranya, dia comeback bukan krn cinta kekuasaan, tapi karena memang bangsa dan negaranya membutuhkan figur pemersatu. Lha sampeyan??? (K)
(4) UC: ibaratnya tanaman rumput alang-alang yang mencoba menyamakan dirinya dengan tanaman padi, meski sepintas tampak sama tapi semua orang sdh tahu mana yang jadi hama... (K)

Komentar (3) dan (4) adalah komentar yang muncul pada berita mengenai AA yang akan mencalonkan diri menjadi presiden RI. Keinginan AA tersebut mendapat respon dari pembaca berita. Kesantunan ditunjukkan dengan memberikan kritik atau penilaian secara tidak langsung penilaian tersebut disampaikan kepada AA dengan tujuan agar mengurungkan niatnya mencalonkan menjadi presiden RI.

\section{Penggunaan Kata Kunci}

Pranowo (2009: 104) memberikan saran agar tuturan dapat mencerminkan rasa santun, yakni sebagai berikut.

a. Gunakan kata "tolong" untuk meminta bantuan pada orang lain.

b. Gunakan kata "maaf" untuk tuturan yang diperkirakan akan menyinggung perasaan lain.

c. Gunakan kata "terima kasih" sebagai penghormatan atas kebaikan orang lain.

d. Gunakan kata "berkenan" untuk meminta kesediaan orang lain melakukan sesuatu.

e. Gunakan kata "beliau" untuk menyebut orang ketiga yang dihormati.

f. Gunakan kata "Bapak/Ibu" untuk menyapa orang ketiga.

Kata-kata yang disarankan Pranowo di atas, oleh peneliti disebut sebagai kata kunci kesopansantunan berbahasa. Pada komentar berita politik di facebook tidak banyak yang menggunakan kata kunci tersebut.

g. Selamat buat pak Ridwan Kamil, sekiranya wakilnya pak Dedy 
Mulyadi maka Jabar akan semakin maju. Mereka adalah pasangan yang cerdas dan punya jiwa sosial kepada rakyat kecil. Masih banyak di jabar yang mau dibenahi termasuk jalanan yang tambal sulam, macet, kotor/sampah, trotoar kurang tertata rapi, angkutan yang sembarangan ngetem. $(\mathrm{K})$

h. RS: Saya ucapkan terimakasih banyak atas kerja kerasnya kepada semua pihak, saya hanya memberikan masukan atau usulan.

i. WES: @S kasihan mas klo mas menertawakan orang sampai maaf sakit seperti itu.. ini tandanya mas ga punya rasa empati sama orang lain, apalagi nasib bangsa sendiri . maaf saya rakyat dan saya menginginkan \#2019gantipresiden..karena saya perduli penderitaan teman2 rakyat sekitar saya..huhu (KdK).

\section{Penggunaan Kalimat Bersifat Empati}

Empati diartikan sebagai perasaan simpati dan perhatian terhadap orang lain, khususnya untuk berbagi pengalaman atau secara tidak langsung merasakan penderitaan orang lain (Sears, dkk dalam Yuli Asih 2010: 35). Hal senada diungkapkan oleh Hurlock (dalam Yuli Asih 2010:35) yang mengungkapkan bahwa empati adalah kemampuan seseorang untuk mengerti tentang perasaan dan emosi orang lain serta kemampuan untuk membayangkan diri sendiri di tempat orang lain. Leiden, dkk (dalam Yuli Asih 2010:36) menyatakan empati sebagai kemampuan menempatkan diri pada posisi orang lain sehingga orang lain seakan-akan menjadi bagian dalam diri. Lebih lanjut dijelaskan oleh Baron dan Byrne yang menyatakan bahwa empati merupakan kemampuan untuk merasakan keadaan emosional orang lain, merasa simpatik dan mencoba menyelesaikan masalah, dan mengambil perspektif orang lain.

Pernyataan empati secara verbal termasuk dalam bentuk kesopansantunan berbahasa. Kalimat-kalimat bersifat empati nampak dalam kalimat-kalimat berikut.

(11) S: Yang jagoannya menang jangan tinggi hati yang jagoannya kalah jangan kecil hati, saling menghormati dan saling merangkul untuk membangun JABAR yang RINDU JUARA biar hidup jadi ASIK(K)

(12) RT: kita dukung lah.. biar jelas nanti pendapat masyarakat seperti apa, mendukung beliau atau tidak... jadi deh duel secara fair seperti yang di inginkan ...itulah hidup ber demokrasi (K)

\section{SIMPULAN DAN SARAN}

Kesantunan berbahasa dalam unggahan berita dan komentar nampak dalam empat hal, yaitu (1) penggunaan pronomina, (2) penggunaan bentuk ketidaklangsungan, (3) penggunaan kata kunci, dan (4) penggunaan kalimat bersifat empati. Penelitian lanjutan dapat dilakukan dengan data yang sama dengan pendalaman masalah penelitian, seperti ilokusi, implikatur, serta realisasi prinsip-prinsip kerja sama atau prinsip-prinsip kesantunan. Selain itu, penelitian terhadap data yang sama dapat dikembangkan dengan klasifikasi data berdasarkan kategori tertentu, seperti jenis unggahan berita dan kometar sehingga didapatkan kriteria kesantunan yang lebih spesifik. Penelitian dengan tinjauan sosiolinguistik juga dapat dilakukan dengan data yang sama, melihat fenomena kebahasaan pada unggahan berita dan komentar pembaca dari sudut pandang sosial kebahasaan. 


\section{DAFTAR PUSTAKA}

Baryadi, Praptomo. 2005. "Teori Sopan Santun Berbahasa"dalam Pranowo, dkk.(Eds.)Bahasa, Sastra, dan Pengajarannya. Yogyakarta: Sanata Dharma University Press.

Kurniawan, Puguh. 2017. "Pemanfaatan Media Sosial Instagram Sebagai Komunikasi Pemasaran Modern Pada Batik Burneh" dalam Jurnal Kompetensi, Vol 11, No 2, Oktober. Hlm.217-225

(file:///C:/Users/X200MA/Downloads/3 533-8482-1-SM.pdf) .

Kushartanti. 2005. Pesona Bahasa Langkah Awal Memahami Sosiolinguistik. Jakarta: Gramedia.

Pranowo. 2009. Kesantunan Berbahasa Tokoh Masyarakat. Yogyakarta: Universitas Sanata Dharma.
Pranowo. 2009. Berbahasa Secara Santun: Yogyakarta: Pustaka Pelajar.

Rahardi, Kunjana. 2005. Pragmatik: Kesantunan Imperatif Bahasa Indonesia. Jakarta: Penerbit Erlangga

Sudaryanto. 2015. Metode dan Aneka Teknik Analisis Bahasa: Pengantar Penelitian Wahana Kebudayaan Secara Linguistis. Yogyakarta: Sanata Dharma University Press.

Yuli Asih dan Margaretha Maria. 2010. "Perilaku Prososial Ditinjau dari Empati dan Kematangan Emosi" dalam Jurnal Psikologi Sunan Muria Kudus, Psikologi Sunan Muria Kudus, Vol 1, No 1 halaman 33-42. 